\title{
Produk Roti dalam Pola Konsumsi Pangan dan Keberadaan Label Halal dalam Keputusan Konsumsi Masyarakat (Kasus: Kota Bogor)
}

\section{Bread Products in Food Consumption Patterns and Existence of Halal Label in Society Consumption Decision (Case: Bogor City)}

\author{
Silmy Kania Rizka ${ }^{1}$, Yeti Lis Purnamadewi ${ }^{2}$, Neneng Hasanah ${ }^{3}$ \\ ${ }^{1}$ Departemen Ilmu Ekonomi Syariah, Institut Pertanian Bogor 16680, email: silmykania@gmail.com \\ ${ }^{2}$ Departemen Ilmu Ekonomi, Institut Pertanian Bogor 16680, email: yetilispurnama@yahoo.com \\ ${ }^{3}$ Departemen Ilmu Ekonomi Syariah, Institut Pertanian Bogor 16680, email: nenengnajaah3@gmail.com
}

\begin{abstract}
The pattern of bread consumption has increased significantly compared to the increase in the average in rice consumption. However, the increase in bread consumption was not balanced by the increase in the producers' awareness to have halal certificate. Meanwhile, halal certified products are only about $11.6 \%$ of the total existing products in Indonesia. For this reason, this study aims to analyze the consumption pattern of bread products, consumer's perceptions of the halal labels and their influence on the decision to purchase halal-labeled bread products, and factors that influence the decision. The method used in this research are logistic regression and qualitative descriptive. The results of the analysis shows that bread products are the second source of carbohydrates after rice and the higher the income class have a higher level of bread product consumption. Based on the consumer's perception, the existence of the halal label in packaging of bread products is a main consideration in the decision of purchasing bread products for most of households consumers, but the perception and a fact of the purchasing have not been consistent. The results of the logistic regression analysis shows that the variable of halal awareness, duration of education, dummy of origin area, and dummy of lower income class significantly affect the decision of bread products consumption.
\end{abstract}

Keywords: bread product, consumer's perseption, halal label, logistic regression

\begin{abstract}
Abstrak. Pola konsumsi roti masyarakat mengalami peningkatan yang signifikan dibandingkan dengan peningkatan rata-rata konsumsi nasi. Namun, peningkatannya tidak diimbangi dengan peningkatan kepedulian produsen untuk memiliki sertifikat halal. Produk yang telah memiliki sertifikat halal hanya sekitar $11.6 \%$ dari total produk yang ada di Indonesia. Untuk itu, penelitian ini pun bertujuan untuk menganalisis pola konsumsi produk roti dalam pola konsumsi pangan masyarakat, persepsi konsumen mengenai keberadaan label halal dan pengaruhnya terhadap keputusan pembelian produk roti berlabel halal, dan faktor yang memengaruhi keputusan konsumsi produk roti berlabel halal. Metode yang digunakan adalah regresi logistik dan deskriptif kualitatif. Hasil analisis menunjukkan bahwa produk roti merupakan sumber karbohidrat kedua setelah beras dan semakin tinggi golongan pendapatan, maka semakin tinggi juga tingkat konsumsinya. Berdasarkan persepsi, keberadaan label halal dalam kemasan produk roti merupakan pertimbangan utama dalam keputusan pembelian produk roti bagi sebagian besar konsumen rumah tangga, namun persepsi dan fakta pembelian belum konsisten. Hasil analisis regresi logistik menunjukan bahwa variabel halal awareness, lama pendidikan, dummy asal, dan dummy golongan pendapatan bawah berpengaruh signifikan terhadap keputusan konsumsi produk roti.
\end{abstract}

Kata kunci: label halal, persepsi konsumen, produk roti, regresi logistik

\section{PENDAHULUAN}

Jumlah penduduk Indonesia menurut sensus Badan Pusat Statistika (BPS) pada tahun 2010 mencapai 238.50 juta jiwa dan sekitar $87.18 \%$ dari total penduduk Indonesia beragama Islam. Reuters dan Standard (2015) mengemukakan bahwa makanan dan minuman halal merupakan salah satu peluang paling menjanjikan dalam sektor ekonomi untuk produk halal. Maka dengan melihat data tersebut, Indonesia memiliki peluang yang besar dalam mengembangkan produk halal.

Konsumsi dalam Islam tidak hanya sebagai pemenuh keinginan, tetapi juga untuk mencapai maslahah (P3EI UII, 2013). Mengonsumsi makanan yang halal dan baik (thoyyib) merupakan suatu kewajiban yang harus dipenuhi oleh setiap muslim (QS. Al-Baqarah ayat 168). Menurut hasil polling yang 
diselenggarakan indohalal.com, yayasan Halalan Thoyyiban dan LPPOM MUI pada akhir tahun 2002 menyatakan bahwa sebesar $77.6 \%$ responden menjadikan jaminan kehalalan sebagai pertimbangan pertama dalam berbelanja produk (makanan, minuman, kosmetik, dan resto) (Apriyantono \& Nurbowo, 2003). Dari hasil polling tersebut juga diketahui bahwa 93.9\% responden setuju sertifikasi halal dilakukan dalam setiap produk. Namun, harapan dan keinginan konsumen terhadap kehalalan produk, tidak diimbangi dengan kepedulian produsen. Produk yang telah memiliki sertifikat halal hanya sekitar $11.6 \%$ dari total produk yang ada di Indonesia.

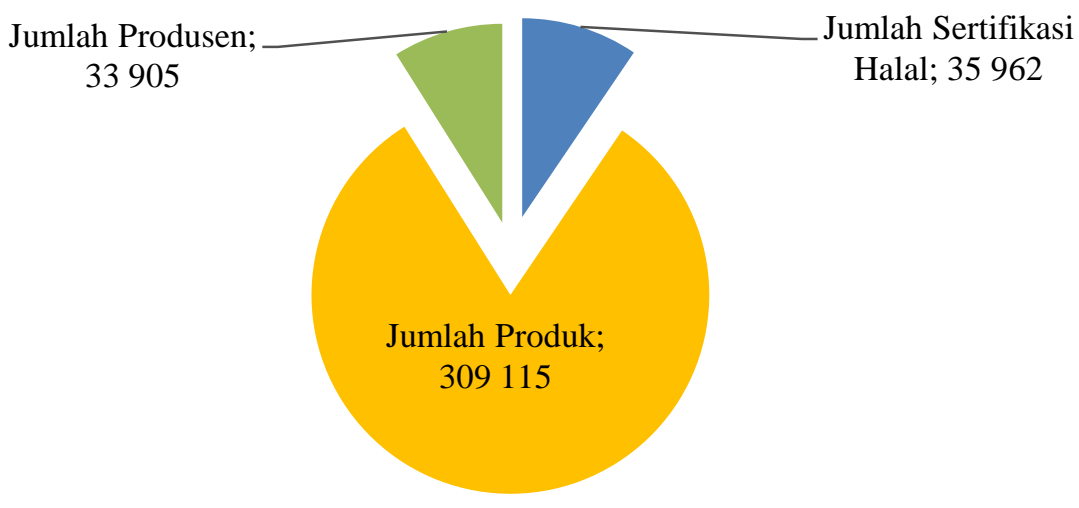

Sumber: Lembaga Pengkajian Pangan Obat obatan dan Kosmetika Majelis Ulama Indonesia (LPPOM MUI)

Gambar 1 Jumlah sertifikasi halal MUI di Indonesia tahun 2010-2015

Dalam Al-Qur'an surat Al-Baqarah ayat 173, Allah SWT mengharamkan bangkai, darah, daging babi, dan binatang yang (ketika disembelih) disebut (nama) selain Allah. Namun di zaman yang semakin modern ini hal-hal yang diharamkan menjadi sulit dibedakan, khususnya makanan dan minuman. Komposisi makanan yang beragam dan zat tambahan yang digunakan sulit ditentukan asal pembuatannya, sehingga produk pangan diragukan kehalalannya. Rasulullah SAW bersabda: "Perkara halal itu jelas dan perkara haram juga jelas. Di antara keduanya ada perkara-perkara syubhat, yang tidak diketahui oleh banyak orang. Barang siapa menjaga diri dari perkara syubhat, ia telah menyelamatkan kehormatan dan agamanya. Sebaliknya, barang siapa terlibat dalam perkara syubhat, ia terperosok ke dalam perkara haram; seperti pengembala yang menggembalakan ternak di sekitar daerah terlarang (padang rumput milik seseorang), ia hampir saja masuk ke dalamnya." (HR. Al-Bukhari Muslim).

Menurut BPS (2016), sosial ekonomi masyarakat dan budaya akan membentuk pola konsumsi masyarakat. Pola konsumsi makanan dapat dikaitkan dengan kondisi kesehatan dan gizi masyarakat. Pola konsumsi makanan penduduk merupakan salah satu indikator sosial ekonomi yang sangat dipengaruhi oleh budaya dan lingkungan setempat. Menurut Pusat Kebijakan Perdagangan Dalam Negeri (2013), tingginya aktivitas masyarakat akibat dari meningkatnya kebutuhan, mengakibatkan pola konsumsi pangan berubah. Perubahan pola gaya hidup dan kebijakan yang berlaku juga merupakan salah satu penyebab perubahan pola konsumsi pangan. Perkembangan zaman yang semakin modern membuat gaya hidup masyarakat mengalami pergeseran, sehingga masyarakat cenderung menginginkan hal-hal yang praktis dan mudah diperoleh.

Berdasarkan data BPS (2017) dapat diketahui bahwa rata-rata pengeluaran per kapita sebulan di daerah perkotaan untuk padi-padian mengalami penurunan sebesar 2.3\% pada tahun 2012 hingga tahun 2014. Sementara rata-rata pengeluaran per kapita sebulan di daerah perkotaan untuk makanan dan minuman jadi terus mengalami peningkatan sebesar 2.5\% pada tahun 2012 hingga tahun 2014 . Maka berdasarkan data tersebut dapat diketahui bahwa pola konsumsi pangan masyarakat mengalami perubahan dari padi-padian ke makanan dan minuman jadi. Beberapa makanan yang termasuk ke dalam makanan dan minuman jadi yaitu, roti, kue, makanan gorengan, mie instan, dan lain-lain. 
Berdasarkan Gambar 2 dapat diketahui bahwa tahun 2011 sampai tahun 2015 rata-rata konsumsi nasi cenderung fluktuatif. Namun konsumsi roti tawar, roti manis, dan roti lainnya cenderung meningkat. Pada tahun 2015 konsumsi nasi mengalami penurunan dari 8708 porsi menjadi 7926 porsi. Sementara rata- rata konsumsi roti pada tahun 2015 mengalami peningkatan yang signifikan dari 29 044 potong menjadi 52143 potong.

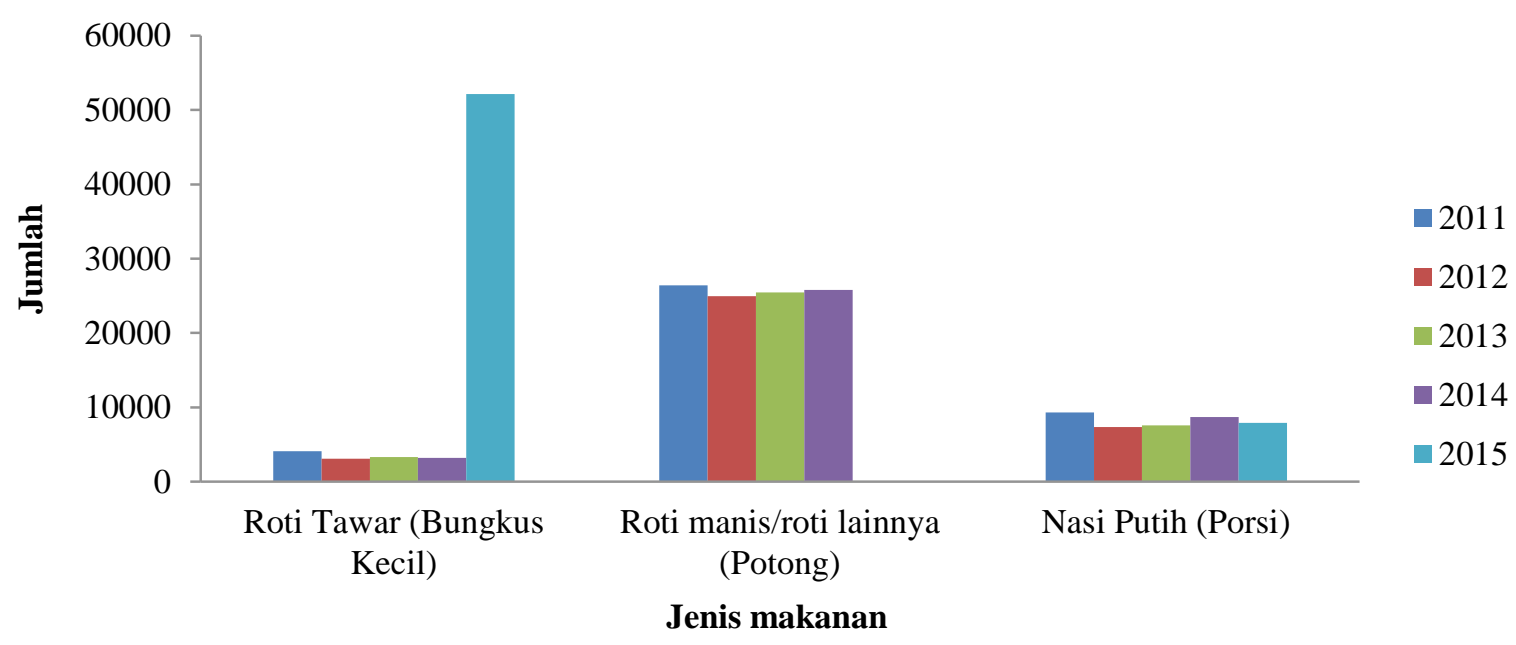

Sumber: BPS (2017)

Gambar 2 Konsumsi per kapita dalam rumah tangga setahun menurut hasil Susenas 2010-2015

Arintawati (2014) menegaskan bahwa roti dan kue merupakan salah satu jenis makanan yang menggunakan bahan tambahan makanan yang sangat kompleks, sehingga ada beberapa titik kritis peluang masuknya bahan haram ke dalam produk bakery. Beberapa bahan yang digunakan dalam pembuatan roti dan kue yang menjadi titik kritis keharaman, yaitu tepung terigu, bahan pengembang, kuas bulu babi, rhum, daging dan produk olahannya, emulsifier, ovalet, shortening, margarin, ragi, keju, creamer, gelatin, TBM, dan coklat (LPPOM MUI, 2014). Sesuatu yang halal jika bercampur dengan sesuatu yang haram sekecil apapun, maka hukumnya menjadi haram (Al-Qaradhawi, 2005). Maka label halal pada produk roti merupakan atribut yang penting dan mendesak untuk konsumen muslim karena beberapa bahan tambahan pembuatan produk roti berada pada titik kritis keharaman.

Menurut Sukesti dan Mahdukh (2014), label halal memengaruhi keputusan pembelian produk makanan. Namun, hanya sedikit industri roti dan kue yang sudah memiliki sertifikat halal. Hal tersebut merugikan hak konsumen muslim karena konsumen tidak mendapatkan kepastian mengenai kehalalan produk. Padahal label halal pada produk roti merupakan atribut yang penting dan mendesak untuk konsumen muslim. Maka sangat disayangkan, jika konsumsi roti dan kue yang tinggi tidak diimbangi dengan keinginan produsen untuk memenuhi hak konsumen muslim. Oleh karena itu, penting untuk dilakukan penelitian lebih lanjut mengenai konsumsi produk roti dalam pola konsumsi pangan masyarakat, persepsi konsumen mengenai keberadaan label halal dan pengaruhnya terhadap keputusan pembelian produk roti berlabel halal, dan faktor yang memengaruhi keputusan konsumsi produk roti berlabel halal.

\section{TINJAUAN PUSTAKA}

Halal adalah sesuatu yang boleh, yang terbebas dari ikatan larangan-larangan, dan telah diizinkan oleh syariat dalam melakukannya (Al-Qaradhawi, 2005). Menurut Burhanuddin (2011), produk halal adalah produk yang memenuhi syarat kehalalan sesuai syariat Islam, yaitu tidak mengandung babi dan bahan yang berasal dari babi. Selain itu, semua bahan berasal dari hewan halal yang disembelih sesuai 
syariat Islam. Tempat penyimpanan, penjualan, pengolahan, dan transportasi produk tidak pernah digunakan untuk barang yang tidak halal. Produk halal juga tidak mengandung khamar dan bahanbahan yang diharamkan (organ manusia, darah, kotoran, dan lainnya). Allah SWT berfirman: "Maka makanklah yang halal lagi baik dari rezeki yang telah diberikan Allah kepadamu, dan syukurilah nikmat Allah, jika kamu hanya kepada-Nya saja menyembah.” (QS. An-Nahl ayat 114).

Menurut Apriyantono et al. (2007) sertifikasi halal adalah sertifikat yang menyatakan kehalalan suatu produk yang dikeluarkan oleh lembaga yang diakui dan kredibel. Di Indonesia lembaga yang bertugas untuk melakukan sertifikasi halal adalah Lembaga Pengkajian Pangan Obat-obatan dan Kosmetika (LPPOM MUI). Sertifikat Halal MUI merupakan syarat untuk produsen pangan, kosmetik, obatobatan, maupun produk lainnya untuk memperoleh izin pencantuman label halal (LPPOM MUI, 2017). Sertifikasi halal dilakukan untuk memenuhi kebutuhan dan tuntunan konsumen muslim khususnya, untuk memmberi kepastian mengenai kehalalan produk yang akan dikonsumsi. LPPOM MUI merupakan suatu lembaga yang dibentuk oleh MUI untuk melakukan pemeriksaan dan sertifikasi halal. LPPOM MUI didirikan pada tanggal 6 Januari 1989.

Produk bakery adalah produk makanan yang bahan utamanya adalah tepung (umumnya tepung terigu) dan dalam pengolahannya melibatkan proses pemanggangan (Apriyantono, 2009). Menurut Syarbini (2014) produk bakery dapat digolongkan menjadi empat klasifikasi:

1 Roti merupakan makanan yang terbuat dari bahan utama tepung terigu, yeast/ragi, garam dan air, serta bahan tambahan lain: gula, margarin, telur, susu, dan lainnya. Ada beberapa contoh produk roti, yaitu: roti manis, roti tawar, country bread, rye bread, dan lain-lain.

2 Cake merupakan produk makanan manis yang terbuat dari bahan utama tepung terigu, gula, telur, dan margarin. Pound cake, sponge cake, dan muffin merupakan salah satu contoh cake.

3 Pastry merupakan jenis produk bakery yang terbuat dari bahan: tepung terigu, lemak, gula, garam, air, dan bahan lainnya. Perbedaan pastry dengan produk bakery lainnya adalah penggunaan laminating fat atau lemak semi padat yang digunakan dalam pembentukan adonan. Short crust pastry dan puff pastry merupakan salah satu contoh pastry.

4 Biskuit/cookies merupakan produk kue kering yang terbuat dari bahan utama: tepung terigu, telur, margarin dengan tambahan bahan lain seperti coklat, kacang almond, kacang mede, dan lain-lain. Cracker merupakan salah satu contoh produk biskuit.

Apriyantono (2009) menyatakan bahwa ada beberapa bahan dalam produk roti dan kue yang dipertanyakan status kehalalannya, yaitu:

1 Plasma darah (dalam bentuk isolat protein plasma) sebagai pengganti sebagian tepung gandum pada pembuatan roti, juga sebagai pengganti putih telur pada pembuatan angel food cake.

2 L-sitein merupakan zat aditif yang digunakan sebagai improving agent/meningkatkan sifat-sifat tepung gandum yang diinginkan. L-sistein terbuat dari rambut manusia/bulu unggas.

3 Cream of tartar merupakan garam potasium dari asam tartarat yang diperoleh sebagai hasil samping industri wine. Cream of tartar ada pada baking powder.

4 Emulsifier bisa terbuat dari bahan nabati atau hewani, biasanya dicampur dengan lemak padat. Jenis lemak yang digunakan tidak jelas, sehingga status kehalalannya dipertanyakan. Emulsifier digunakan untuk penstabil dalam proses pembuatan ragi dan pelembut adonan kue.

5 Dough conditioner mengandung L-sistein, tepung kedelai, asam karbonat, lemak, gula, pengawet, emulsifier dan gipsum. Dough conditioner memiliki status syubhat karena mengandung L-sistein, lemak dan emulsifier.Biasa dignakan untuk melembutkan dan mengembangkan adonan, memprpanjang umur roti, dan lain-lain.

6 Shortening terbuat dari lemak atau campuran yang memiliki sifat plastisitas, lemak tersebut bisa terdiri dari lemak nabati saja campuran lemak nabati dengan lemak hewani atau lemak ikan atau campuran lemak hewani (lemak sapi dan lemak babi). Shortening biasanya digunakan untuk membuat adonan kue ataupun roti menjadi lembut.

7 Gelatin terbuat dari bahan yang kaya akan kolagen seperti kulit dan tulang, baik dari sapi ataupun babi. Namun, apabila menggunakan kulit atau tulang sapi membutuhkan proses yang lama dan 
memerlukan penetral yang lebih banyak. Gelatin biasanya digunakan untuk menjaga kelembapan produk, sebagai perekat bahan pengisi pada roti-rotian dan lain-lain.

8 Dan lain-lain.

Menurut Diana (2012), konsumsi adalah mengeluarkan sesuatu dalam rangka memenuhi kebutuhan. Konsumsi meliputi keperluan, kesenangan, dan kemewahan. Dalam Islam kesenangan diperbolehkan asal tidak berlebihan atau melampaui batas (QS. Al A'raaf ayat 7). Konsumsi dalam Islam tidak hanya sekadar memenuhi keinginan namun ada beberapa prinsip yang harus dipenuhi, yaitu: halal, baik/ bergizi, konsumsi secukupnya/tidak berlebihan, tidak mengandung riba, tidak kotor/najis dan tidak menjijikan, dan bukan dari hasil suap (Diana, 2012).

\section{METODE}

\section{Lokasi dan Waktu Penelitian}

Penelitian ini dilakukan di Kota Bogor. Pemilihan wilayah dilakukan berdasarkan beberapa pertimbangan utama, yaitu mayoritas penduduk Kota Bogor beragama Islam, letak geografis Kota Bogor strategis sehingga perekonomian berkembang dan tumbuh lebih cepat, serta industri makanan khususnya industri produk roti merupakan salah satu industri yang berkembang di Kota Bogor. Pengumpulan data dilaksanakan pada bulan Mei 2017 sampai dengan Juni 2017 dan bulan Agustus 2017.

\section{Jenis, Sumber, dan Metode Pengumpulan Data}

Penelitian ini menggunakan metode survey, sehingga data utama yang digunakan adalah data primer. Data primer diperoleh melalui pengamatan dan wawancara dengan menggunakan kuesioner. Wawancara dilakukan kepada rumah tangga muslim yang menjadi sampel penelitian di Kota Bogor. Data lain yang digunakan pada penelitian ini adalah data sekunder. Data sekunder diperoleh dari laporan tahunan, buku, literatur, dan media internet.

\section{Metode Penentuan Sampel}

Sebagaimana sudah disampaikan bahwa data utama dalam penelitian ini adalah data primer yang dikumpulkan dari sampel rumah tangga muslim karena unit analisis dalam penelitian ini adalah rumah tangga. Responden yang diwawancara adalah salah satu anggota rumah tangga yang mengetahui kondisi rumah tangga termasuk dalam hal konsumsi roti dan sebagian besar anggota rumah tangga yang diwawancara adalah ibu rumah tangga. Sampel rumah tangga muslim dalam penelitian ini dibedakan atau mencakup rumah tangga golongan pendapatan rendah, rumah tangga golongan pendapatan sedang, dan rumah tangga golongan pendapatan tinggi. Penggolongan rumah tangga berdasarkan golongan pendapatan dilakukan dengan asumsi bahwa terdapat perbedaan konsumsi produk roti dalam pola konsumsi pangan antara ketiga golongan pendapatan. Menurut Sawit (2003), tingkat konsumsi terigu dan makanan yang berasal dari terigu seperti mie dan roti paling tinggi dikonsumsi oleh golongan pendapatan tinggi, yaitu sekitar 40 sampai 60 kali lebih tinggi dibandingkan golongan pendapatan rendah.

Penentuan sampel dilakukan dengan menggunakan metode klaster (cluster sampling) dan purposive sampling. Teknik klaster merupakan teknik yang digunakan apabila dalam suatu populasi terdapat kelompok-kelompok yang memiliki karakteristik yang sama (Idrus, 2009). Teknik klaster digunakan jika obyek yang akan diteliti terlalu luas, sedangkan karakteristik antar kelompoknya hampir sama dan semua klaster memiliki anggota yang heterogen (Suliyanto, 2009). Setelah melakukan pengelompokan atau klasterisasi, sampel dipilih melalui metode purposive sampling. Metode puposive sampling merupakan metode yang digunakan jika terdapat pertimbangan-pertimbangan tertentu dalam pengambilan sampelnya (Idrus, 2009). 
Tabel 1 Jumlah sampel penelitian berdasarkan golongan pendapatan

\begin{tabular}{lcccc}
\hline \multirow{2}{*}{ Keterangan } & \multicolumn{4}{c}{ Klaster } \\
\cline { 2 - 5 } & I & II & III & Total \\
\hline Jumlah sampel rumah tangga & 10 & 12 & 18 & 40 \\
Persentase (\%) & 25 & 30 & 45 & 100 \\
\hline Syyyyy
\end{tabular}

Sumber: Data primer (2017)

Penentuan klaster dalam penelitian ini menggunakan data BPS, yaitu Kota Bogor dalam Angka 2016 Bab Kemiskinan Subbab Jumlah Keluarga menurut Tahapan Kesejahteraan. Berdasarkan data tersebut diketahui bahwa Kecamatan Bogor Selatan merupakan wilayah dengan jumlah keluarga pra-sejahtera dan sejahtera I terbanyak dibandingkan kecamatan lain di kota Bogor, yakni sebesar $7.88 \%$ keluarga pra-sejahtera dan $20.04 \%$ keluarga sejahtera I dari total keluarga di Kecamatan Bogor Selatan. Menurut Puspitawati (2013), keluarga pra-sejahtera sering dikategorikan sebagai sangat miskin dan keluarga sejahtera I dikategorikan sebagai miskin. Kecamatan Tanah Sareal merupakan wilayah dengan jumlah keluarga sejahtera II terbanyak dibanding kecamatan lain di Kota Bogor, yakni sebesar 51.02\% keluarga dari total keluarga di Kecamatan Tanah Sareal dan rata-rata penduduknya memiliki pendapatan menengah. Kecamatan Bogor Barat merupakan wilayah dengan jumlah keluarga sejahtera III dan sejahtera III+ terbanyak dibanding kecamatan lain di Kota Bogor, yakni sebesar 29.07\% keluarga sejahtera III dan $7.66 \%$ keluarga sejahtera III+ dan rata-rata penduduknya memiliki pendapatan tinggi.

Berdasarkan penjelasan sebelumnya, pembagian klaster dalam penelitian ini, yaitu Kecamatan Bogor Selatan termasuk ke dalam klaster golongan pendapatan rendah atau klaster I. Kecamatan Tanah Sareal termasuk klaster golongan pendapatan sedang atau klaster II. Selanjutnya, Kecamatan Bogor Barat termasuk ke dalam klaster golongan pendapatan tinggi atau klaster III.

Maka setelah diperoleh wilayah penelitian berdasarkan klaster, sampel dipilih menggunakan metode purposive sampling. Hal tersebut dilakukan karena terdapat beberapa pertimbangan dalam menentukan sampel. Pertimbangan yang dimaksud, yaitu responden harus muslim dan responden yang dipilih harus sesuai dengan wilayah pengklasterannya. Maksudnya, responden yang dipilih pada klaster I merupakan responden yang tinggal di Bogor Selatan dan memiliki pendapatan rendah. Responden yang termasuk ke dalam klaster II merupakan responden yang tinggal di Tanah Sareal dan termasuk ke dalam kategori pendapatan menengah. Selanjutnya, responden pada klaster III merupakan responden yang tinggal di Bogor Barat dan memiliki pendapatan tinggi. Sampel pada setiap klaster memiliki jumlah yang berbeda. Hal tersebut dilakukan karena berdasarkan penelitian konsumsi roti tertinggi dilakukan oleh golongan pendapatan tinggi (Sawit, 2003). Maka jumlah sampel pada golongan pendapatan tinggi sekitar $45 \%$ dari total sampel atau 18 orang. Jumlah sampel pada golongan pendapatan sedang sekitar 30\% dari total sampel atau sekitar 12 orang. Sementara, jumlah sampel pada golongan pendapatan rendah sekitar 10 orang atau 25\% dari total sampel.

\section{Metode Pengolahan dan Analisis Data}

Metode analisis data yang digunakan adalah metode deskriptif kualitatif dan kuantiatif serta metode kuantitatif. Metode deskriptif kualitatif dan kuantitatif digunakan untuk mengkaji karakteristik sampel, mengkaji pola konsumsi produk roti, dan menganalisis persepsi responden mengenai label halal. Metode kualitatif dilakukan dengan analisis desktiptif. Metode kuantitatif digunakan untuk menganalisis faktor-faktor yang memengaruhi keputusan konsumsi produk roti berlabel halal. Pengolahan data kuantitatif dilakukan dengan analisis regresi logistik menggunakan Microsoft Excel 2010 dan SPSS 24.

Dalam penelitian ini, responden yang memilih produk roti berlabel halal merupakan responden yang konsisten memilih produk roti berlabel halal. Responden yang tidak memilih produk roti berlabel halal merupakan responden yang tidak konsisten memilih produk roti berlabel halal, baik selalu memilih produk roti yang tidak berlabel halal maupun yang terkadang memilih produk roti yang tidak berlabel halal. Maka model yang digunakan dalam penelitian ini yaitu: 


$$
L i=\alpha+\beta_{1} P M H+\beta_{2} P K R+\beta_{3} H A A+\beta_{4} P D K+\beta_{5} D A S+\beta_{6} D G A+B_{7} D G R+\varepsilon_{i}
$$

Keterangan:

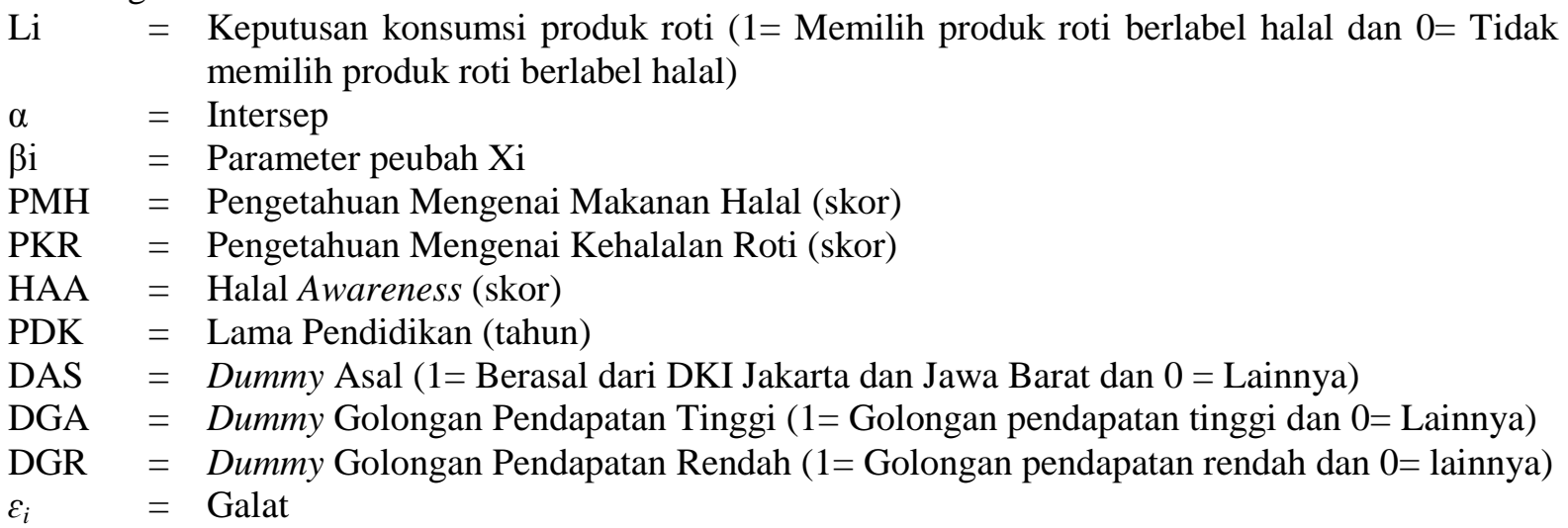

\section{HASIL DAN PEMBAHASAN}

\section{Pengetahuan Responden Mengenai Produk Roti}

Berdasarkan Tabel 2 dapat diketahui bahwa sebagian besar responden, baik pada golongan pendapatan rendah, sedang, maupun tinggi sudah mengetahui beberapa manfaat dan bahan yang digunakan dalam pembuatan produk roti. Pada golongan pendapatan sedang sebagian besar mengaku sudah mengetahui bahan pembuatan roti serta manfaatnya. Selanjutnya, pada golongan pendapatan tinggi sebagian besar sudah mengetahui manfaat dan bahan pembuatan roti. Sebagian besar responden sudah mengetahui potensi ketidakhalalan beberapa bahan yang digunakan dalam pembuatan produk roti. Sebagian responden meyakini bahwa beberapa bahan yang digunakan berpotensi menggunakan campuran bahan yang tidak halal, sehingga bahan tersebu menjadi syubhat atau tidak jelas kehalalannya.

Tabel 2 Distribusi responden berdasarkan golongan pendapatan dan pengetahuan mengenai produk roti

\begin{tabular}{lccc}
\hline \multirow{2}{*}{ Pengetahuan mengenai produk roti } & \multicolumn{3}{c}{ Jumlah responden (\%) } \\
\cline { 2 - 4 } & I & II & III \\
\hline Proses membuat roti & 70 & 83.3 & 72.2 \\
\hline Bahan: & 90 & 100 & 72.2 \\
1. Baking powder & 20 & 66.7 & 72.2 \\
2. Gelatin & 80 & 83.3 & 77.8 \\
3. Rhum & 90 & 100 & 77.8 \\
4. Ragi & 0 & 33.3 & 33.3 \\
5. L-sistein & & & \\
Manfaat: & 60 & 83.3 & 72.2 \\
1. Baking powder & 0 & 41.7 & 55.6 \\
2. Gelatin & 40 & 75 & 72.2 \\
3. Rhum & 90 & 91.7 & 66.7 \\
4. Ragi & 0 & 25 & 27.8 \\
5. L-sistein & 90 & 83.3 & 88.9 \\
\hline Potensi ketidakhalalan bahan roti & & & \\
\hline Sumber: Da primer (2017)
\end{tabular}

Sumber: Data primer (2017) 


\section{Pola Konsumsi Pangan Rumah Tangga Responden Menurut Sumber Gizi}

Widianis (2014) menyatakan bahwa pendapatan, harga komoditas itu sendiri, harga komoditas lain, wilayah tempat tinggal, dan tingkat pendidikan kepala rumah tangga mengakibatkan terjadinya perbedaan pola konsumsi pangan. Berdasarkan Tabel 3, alokasi pengeluaran terbesar pada golongan pendapatan rendah, sedang, dan tinggi adalah untuk konsumsi pangan sumber protein dari total pengeluaran untuk produk pangan. Pada golongan pendapatan rendah alokasi pengeluaran terbesar kedua adalah untuk konsumsi sumber karbohidarat. Pada golongan pendapatan sedang alokasi pengeluaran terbesar kedua adalah untuk konsumsi sumber vitamin. Sementara itu, pada golongan pendapatan tinggi alokasi pengeluaran terbesar kedua adalah untuk konsumsi sumber lainnya.

Tabel 3 Pola konsumsi pangan rumah tangga responden menurut sumber gizi

\begin{tabular}{|c|c|c|c|c|c|c|}
\hline \multirow{3}{*}{ Pangan } & \multicolumn{6}{|c|}{ Pola konsumsi } \\
\hline & \multicolumn{2}{|r|}{ I } & \multicolumn{2}{|r|}{ II } & \multicolumn{2}{|r|}{ III } \\
\hline & $(\%)$ & (Rp/tahun) & $(\%)$ & (Rp/tahun) & $(\%)$ & (Rp/tahun) \\
\hline $\begin{array}{l}\text { Sumber } \\
\text { karbohidrat }\end{array}$ & 26 & 4107600 & 17 & 4904687 & 16 & 6472267 \\
\hline Sumber protein & 38 & 5892000 & 45 & 12910000 & 38 & 15545778 \\
\hline Sumber vitamin & 19 & 2988000 & 22 & 6355000 & 21 & 8544444 \\
\hline Sumber lainnya & 17 & 2670000 & 16 & 4470000 & 25 & 10164444 \\
\hline Total & 100 & 15657600 & 100 & 28639687 & 100 & 40726933 \\
\hline
\end{tabular}

Sumber: Data primer (2017)

\section{Produk Roti dalam Pola Konsumsi Pangan Sumber Karbohidrat Rumah Tangga Responden}

Intensitas mengkonsumsi roti pada golongan pendapatan rendah rata-rata sekitar dua sampai empat kali per bulan atau berada pada kategori kadang-kadang (Tabel 4). Namun, sekitar $47.7 \%$ responden pada golongan pendapatan sedang mengaku mengkonsumsi roti sekitar lebih dari lima kali per minggu atau dapat dikategorikan sebagai rutin mengonsumsi roti. Sekitar $66.7 \%$ responden pada golongan pendapatan tinggi mengaku mengkonsumsi roti sekitar dua sampai empat kali per minggu atau berada pada kategori sering.

Tabel 4 juga menunjukkan bahwa pada umumnya sebagian besar responden mengkonsumsi roti sebagai makanan ringan. Namun, pada golongan pendapatan sedang dan tinggi manfaat mengkonsumsi roti selain sebagai makanan ringan juga sebagai makanan pokok.

Tabel 4 Distribusi responden berdasarkan golongan pendapatan dan intensitas dan manfaat mengkonsumsi produk roti

\begin{tabular}{llccc}
\hline \multirow{2}{*}{ Uraian } & & \multicolumn{3}{c}{ Jumlah responden (\%) } \\
\cline { 2 - 5 } & Tidak pernah & I & II & III \\
\hline \multirow{3}{*}{ Intensitas meng-konsumsi } & $<2$ kali/ bulan & 30 & 0 & 0 \\
& $2-4$ kali/ bulan & 50 & 33 & 11 \\
& $2-4$ kali/ minggu & 20 & 25 & 67 \\
& $\geq 5$ kali/minggu & 0 & 42 & 6 \\
\hline Total & & 100 & 100 & 100 \\
\hline Manfaat meng-konsumsi & Makanan Pokok & 0 & 17 & 0 \\
& Makanan Ringan & 100 & 58 & 78 \\
Total & Makanan Pokok dan Makanan Ringan & 0 & 25 & 28 \\
& & 100 & 100 & 100 \\
\hline
\end{tabular}

Sumber: Data primer (2017)

Tabel 5 menunjukan bahwa konsumsi sumber karbohidrat pada golongan pendapatan rendah terdiri dari beras, roti, dan mie instan. Namun, pangan sumber karbohidrat pada golongan sedang dan tinggi 
lebih variatif. Pada golongan pendapatan sedang konsumsi sumber karbohidrat terdiri dari beras, roti, kentang, umbi-umbian, dan mie instan. Pada golongan pendapatan tinggi konsumsi pangan sumber karbohidrat terdiri dari beras, roti, umbi-umbian, dan mie instan. Namun, umumnya pengeluaran pangan sumber karbohidrat terbesar dialokasikan untuk konsumsi beras, baik pada golongan pendapatan rendah, sedang, maupun tinggi.

Tabel 5 Pola konsumsi sumber karbohidrat rumah tangga responden per kapita per bulan berdasarkan pengeluaran

\begin{tabular}{lrrrrrr}
\hline \multirow{2}{*}{ Pangan } & \multicolumn{3}{c}{ Pola konsumsi } \\
\cline { 2 - 7 } & \multicolumn{2}{c}{ I } & \multicolumn{2}{c}{ II } & \multicolumn{2}{c}{ III } \\
\cline { 2 - 8 } & 71.4 & 59221 & 52.2 & 49480 & 51.1 & (Rp/bulan) \\
\hline Beras* & 16.5 & 13685 & 41.0 & 38874 & 44.5 & 57750 \\
Roti** & 0.0 & 0 & 2.0 & 1875 & 0.0 & 0 \\
Kentang* & 0.0 & 0 & 0.2 & 208 & 0.5 & 607 \\
Umbi-umbian* & 12.2 & 10083 & 4.5 & 4271 & 4.0 & 5148 \\
Mie instan* & 100.0 & 82989 & 100.0 & 94708 & 100 & 129780 \\
\hline Total & & & & & & \\
\hline
\end{tabular}

Ket: *Belum siap makan

**Siap makan

Sumber: Data primer (2017)

Alokasi pengeluaran pangan sumber karbohidrat untuk konsumsi roti pada golongan pendapatan rendah hanya sekitar $16.60 \%$ per bulan. Namun, pengeluaran roti pada golongan pendapatan sedang sekitar $41 \%$ dari total pengeluaran produk pangan sumber karbohidrat, per bulan. Pengeluaran roti pada golongan pendapatan tinggi memiliki persentase tertinggi jika dibandingkan dengan golongan pendapatan lainnya, yaitu $44.5 \%$ per bulan.

Pada Tabel 6 diketahui bahwa rumah tangga golongan pendapatan rendah memiliki pola konsumsi beras 18 kali lebih tinggi jika dibandingkan dengan konsumsi roti, atau sekitar $5.80 \mathrm{~kg}$ per kapita per bulan dan konsumsi roti sekitar $0.31 \mathrm{~kg}$ per kapita per bulan. Pada golongan pendapatan sedang konsumsi beras sekitar $3.91 \mathrm{~kg}$ per kapita per bulan dan konsumsi roti sekitar 4 kali lebih kecil dibandingkan dengan konsumsi beras. Konsumsi beras pada rumah tangga golongan tinggi hampir 3 kali lebih tinggi jika dibandingkan dengan konsumsi roti, yaitu sekitar $4.34 \mathrm{~kg}$ per kapita per bulan dan konsumsi roti sekitar $1.28 \mathrm{~kg}$ per kapita per bulan.

Tabel 6 Pola konsumsi sumber karbohidrat rumah tangga responden per kapita per bulan berdasarkan jumlah

\begin{tabular}{lccc}
\hline & \multirow{2}{*}{ Pangan } & \multicolumn{3}{c}{ Pola Konsumsi } \\
\cline { 2 - 4 } & I & II & III \\
\hline Beras $(\mathrm{kg})$ & 5.80 & 3.91 & 4.34 \\
Roti $(\mathrm{kg})$ & 0.31 & 0.95 & 1.28 \\
Kentang $(\mathrm{kg})$ & 0 & 0.09 & 0 \\
Umbi-umbian $(\mathrm{kg})$ & 0 & 0.01 & 0.17 \\
Mie instan $(\mathrm{kg})$ & 0.28 & 0.42 & 0.21 \\
\hline
\end{tabular}

Sumber: Data primer (2017)

\section{Persepsi Keberadaan Label Halal dan Keputusan Pembelian}

Pada Tabel 7 dapat diketahui bahwa rata-rata skor kepentingan atribut label halal pada setiap golongan pendapatan hampir mencapai empat. Maka dapat disimpulkan bahwa sebagian besar responden menganggap label halal merupakan atribut yang penting dan perlu ada dalam produk roti. Sebagian besar responden mengaku menjadikan atribut label halal sebagai pertimbangan utama atau pertama dalam keputusan pembelian produk roti. 
Tabel 7 Tingkat kepentingan dan pertimbangan mengenai label halal dalam keputusan pembelian

\begin{tabular}{lccc}
\hline \multirow{2}{*}{ Persepsi tentang Label Halal } & \multicolumn{3}{c}{ Jumlah } \\
\cline { 2 - 4 } & I & II & III \\
\hline Skor tingkat kepentingan label halal & 3.90 & 3.75 & 3.89 \\
\hline Pertimbangan pertama (\%) & & & \\
1. Label halal & 60 & 58.3 & 72.2 \\
2. Rasa & 0 & 16.7 & 22.2 \\
3. Tampilan & 0 & 8.3 & 5.6 \\
4. Harga & 30 & 0 & 0 \\
5. Tanggal kadaluwarsa & 10 & 16.7 & 0 \\
\hline Total & 100 & 100 & 100 \\
\hline
\end{tabular}

Sumber: Data primer (2017)

Berdasarkan Gambar 3 diketahui bahwa pada golongan pendapatan rendah sekitar $40 \%$ termasuk ke dalam kategori konsisten memilih produk roti berlabel halal. Pada golongan pendapatan sedang sekitar $41.67 \%$ responden termasuk ke dalam kategori konsisten memilih produk roti berlabel halal. Namun, pada golongan pendapatan tinggi hanya sekitar $27.78 \%$ responden yang konsisten memilih produk roti berlabel halal.

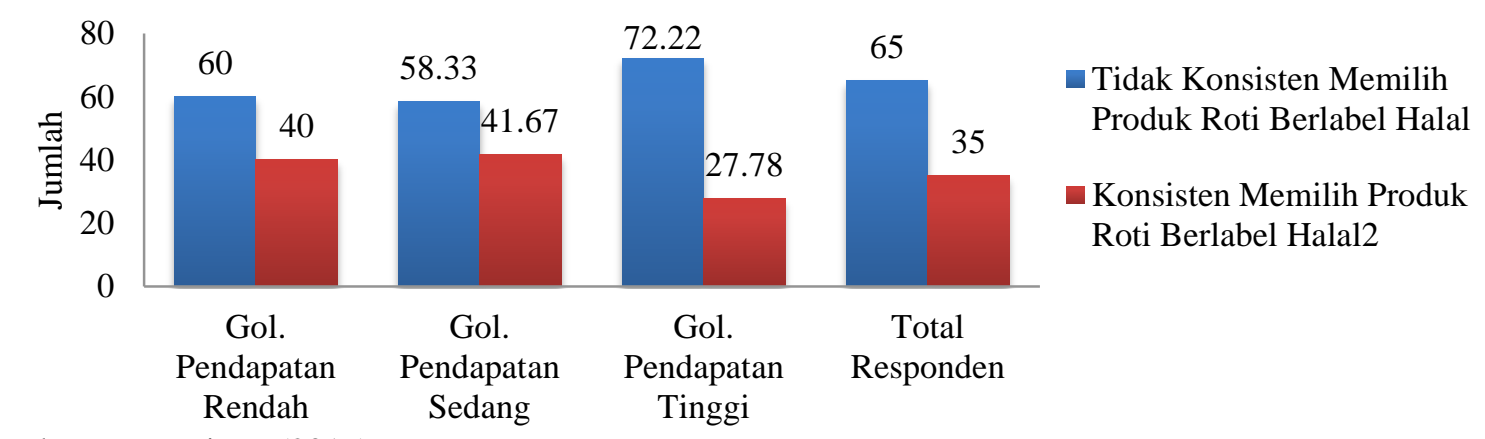

Sumber: Data primer (2017)

Gambar 3 Konsistensi konsumen dalam memilih produk roti berlabel halal

Maka berdasarkan Tabel 7 dan Gambar 3 dapat disimpulkan bahwa persepsi konsumen mengenai label halal tidak terlalu berpengaruh terhadap keputusan pembelian. Persepsi konsumen mengenai label halal sudah baik namun fakta saat pembelian tidak memengaruhi keputusan pembelian produk roti.

\section{Faktor-faktor yang Memengaruhi Keputusan Konsumsi Produk Roti Berlabel Halal}

Sebelum dilakukan analisis hasil dan interpretasi, terlebih dahulu dilakukan uji model dalam regresi logistik. Uji model dilakukan untuk mengetahui kebaiksuaian model dan apakah model dapat menjelaskan tujuan penelitian dengan baik.

\section{Hasil uji model}

Uji Hosmer and Lemeshow digunakan untuk menguji kesesuaian model atau uji Goodness of fit (Hidayat, 2015). Berdasarkan Tabel 8 dapat diketahui nilai Chi-Square hitung 7.937 untuk Df 8 dengan signifikansi 0.440 . Nilai Chi-Square tabel untuk Df 8 pada taraf signifikansi 0.05 adalah 15.507 .

Tabel 8 Dugaan parameter regresi logistik berdasarkan Hosmer and Lemeshow

\begin{tabular}{cccc}
\hline Step & Chi-Square & Df & Sig. \\
\hline 1 & 7.937 & 8 & 0.440 \\
\hline
\end{tabular}


Maka dapat diketahui bahwa, nilai Chi-Square hitung (7.937) kurang dari nilai Chi-Square tabel (15.507) dan nilai signifikansi sebesar 0.440 lebih dari 0.05 , sehingga tidak tolak $\mathrm{H}_{0}$. Artinya, model dapat diterima dan pengujian hipotesis dapat dilakukan sebab ada perbedaan signifikan antara model dengan nilai observasinya (Hidayat, 2015).

Berdasarkan Tabel 9 dapat diketahui nilai Chi-Square hitung untuk Df 7 sebesar 24.133 dengan nilai signifikansi 0.001. Nilai Chi-Square tabel untuk Df 7 pada taraf signifikansi 0.05 adalah 14.067. Maka dapat diketahui bahwa, Chi-Square hitung (24.133) lebih dari Chi-Square tabel (14.067) dan nilai signifikansi sebesar 0.001 kurang dari 0.05 , sehingga tolak $\mathrm{H}_{0}$. Artinya, penambahan variabel independen dapat memberikan pengaruh nyata terhadap model atau dengan kata lain model dinyatakan fit (Hidayat, 2015).

Tabel 9 Dugaan parameter regresi logistik berdasarkan Omnibus Test of Model Coefficients dengan metode Enter

\begin{tabular}{ccccc}
\hline & & Chi-Square & Df & Sig. \\
\hline Step 1 & Step & 24.133 & 7 & 0.001 \\
& Block & 24.133 & 7 & 0.001 \\
& Model & 24.133 & 7 & 0.001 \\
\hline
\end{tabular}

Pada Tabel 10, nilai Nagelkerke R-square sebesar 0.624 memberikan arti bahwa keputusan konsumen dalam membeli produk roti berlabel halal dapat dijelaskan oleh variabel pengetahuan makanan halal, pengetahuan kehalalan roti, halal awareness, lama pendidikan, dummy asal, dummy golongan pendapatan atas, dan dummy golongan pendapatan rendah sebanyak 62.4 persen, dan sisanya dijelaskan oleh faktor lain di luar model.

Tabel 10 Dugaan parameter regresi logistik berdasarkan model summary

\begin{tabular}{cccc}
\hline Step & -2 Log likelihood & Cox \& Snell R Square & Nagelkerke R Square \\
\hline 1 & $27.663^{\mathrm{a}}$ & 0,453 & 0.624 \\
\hline
\end{tabular}

\section{Hasil analisis faktor-faktor yang memengaruhi keputusan konsumsi produk roti berlabel halal}

Dalam penelitian ini, terdapat tujuh variabel independen yang diduga memengaruhi keputusan konsumen dalam memilih produk roti berlabel halal. Variabel independen yang dimaksud mencakup pengetahuan mengenai makanan halal, pengetahuan mengenai kehalalan produk roti, halal awareness, lama pendidikan, dummy asal, dummy golongan pendapatan tinggi, dan dummy golongan pendapatan rendah. Variabel dependen yang digunakan dikategorikan menjadi dua kategori, yakni responden yang memilih produk roti berlabel halal $(\mathrm{Y}=1)$ dan responden yang tidak memilih produk roti berlabel halal $(\mathrm{Y}=0)$.

Tabel 11 menunjukan bahwa berdasarkan analisis regresi logistik, dari tujuh variabel independen yang diduga memengaruhi variabel dependen keputusan konsumsi produk roti berlabel halal, hanya empat variabel independen yang berpengaruh signifikan. Variabel halal awareness berpengaruh positif terhadap keputusan konsumsi produk roti dan signifikan pada taraf nyata 5 persen. Variabel halal awareness memiliki nilai odds ratio sebesar 3.209. Maka, dapat diartikan bahwa konsumen produk roti dengan tingkat halal awareness yang tinggi cenderung memiliki keputusan memilih produk roti berlabel halal 3.209 kali lebih tinggi ceteris paribus.

Hasil uji logistik menunjukan variabel lama pendidikan signifikan dan positif pada taraf nyata 5 persen dan memiliki nilai odds ratio sebesar 1.815. Nilai tersebut memiliki arti bahwa konsumen produk roti dengan durasi pendidikan formal lebih panjang memiliki keputusan konsumsi produk roti berlabel halal 1.815 lebih tinggi ceteris paribus.

Variabel dummy asal berpengaruh negatif dan signifikan terhadap keputusan konsumsi produk roti pada taraf nyata 1 persen. Variabel dummy asal memiliki nilai odds ratio sebesar 0.021. Maka, dapat 
diartikan bahwa konsumen yang berasal dari Jawa Barat dan DKI Jakarta cenderung memiliki keputusan memilih produk roti berlabel halal 0.021 kali lebih rendah ceteris paribus.

Tabel 11 Faktor yang memengaruhi keputusan konsumsi produk roti berlabel halal

\begin{tabular}{lrll}
\hline Variable & \multicolumn{1}{l}{ B } & \multicolumn{1}{l}{ Sig. } & Odds Ratio Exp (B) \\
\hline Constant & -13.812 & 0.149 & 0.000 \\
Pengetahuan Makanan Halal & -0.189 & 0.617 & 0.828 \\
Pengetahuan Kehalalan Roti & -0.129 & 0.558 & 0.879 \\
Halal A wareness & $\mathbf{1 . 1 6 6}$ & $\mathbf{0 . 0 4 9}$ & $\mathbf{3 . 2 0 9}^{*}$ \\
Lama Pendidikan & $\mathbf{0 . 5 9 6}$ & $\mathbf{0 . 0 3 6}$ & $\mathbf{1 . 8 1 5}^{*}$ \\
Dummy Asal & $\mathbf{- 3 . 8 8 3}$ & $\mathbf{0 . 0 0 9}$ & $\mathbf{0 . 0 2 1}^{* *}$ \\
Dummy Golongan Pendapatan Tinggi & -2.055 & 0.152 & 0.128 \\
Dummy Golongan Pendapatan & $\mathbf{4 . 6 1 8}$ & $\mathbf{0 . 0 3 6}$ & $\mathbf{1 0 1 . 2 5 7 ^ { * }}$ \\
Rendah & & & \\
\hline Keterangan: **signifikan pada taraf nyata 1\% & & &
\end{tabular}

Hasil uji logistik menunjukan bahwa variabel dummy golongan pendapatan rendah berpengaruh positif dan signifikan dengan nilai odds ratio sebesar 101.257. Hal ini berarti bahwa konsumen produk roti yang memiliki golongan pendapatan rendah, memiliki keputusan konsumsi produk roti berlabel halal lebih tinggi 101.257 kali daripada golongan pendapatan lainnya ceteris paribus.

\section{SIMPULAN}

Berdasarkan pembahasan yang dipaparkan sebelumnya, maka dapat disimpulkan bahwa:

1 Terdapat perbedaan pola konsumsi produk roti dalam pola konsumsi pangan sumber karbohidrat rumah tangga berdasarkan golongan pendapatan. Secara umum, dibandingkan dengan rumah tangga golongan pendapatan rendah, rumah tangga golongan pendapatan sedang dan tinggi memiliki pengetahuan yang lebih baik. Bagi semua rumah tangga, beras masih merupakan sumber karbohidrat utama dan produk roti merupakan sumber karbohidrat kedua. Namun, semakin tinggi golongan pendapatan maka semakin tinggi juga tingkat konsumsi produk rotinya, baik dari sisi frekuensi konsumsi maupun besarnya konsumsi (pengeluaran dan berat). Bagi rumah tangga golongan pendapatan rendah manfaat mengkonsumsi produk roti hanya sebagai makanan ringan, akan tetapi untuk rumah tangga golongan pendapatan sedang dan tinggi manfaat mengkonsumsi roti sebagai makanan pokok dan makanan ringan.

2 Sebagian besar responden menganggap bahwa label halal penting atau perlu ada dalam kemasan produk roti. Umumnya responden menjadikan label halal sebagai pertimbangan utama atau pertama dalam keputusan pembelian produk roti. Namun, persepsi konsumen mengenai keberadaan label halal tidak terlalu berpengaruh terhadap keputusan pembelian produk roti berlabel halal.

3 Hasil analisis regresi logistik menunjukan bahwa variabel halal awereness, lama pendidikan, dan dummy golongan pendapatan bawah berpengaruh positif dan signifikan terhadap keputusan konsumsi produk roti berlabel halal. Sementara variabel dummy asal berpengaruh negatif signifikan terhadap keputusan konsumsi produk roti.

\section{DAFTAR PUSTAKA}

Al-Qaradhawi, Y. (2005) Halal Haram dalam Islam Cetakan ke-2. Abu Hana Zulkarnain dan Abdurrahim Mu'thi, penerjemah. Jakarta, Akbar Media Eka Sarana.

Apriyantono, A. \& Nurbowo. (2003) Panduan Belanja dan Konsumsi Halal. Jakarta, Khairul Bayaan. Apriyantono, A., Joko, H. \& Nur, W. (2007) Pedoman Produksi Pangan Halal. Jakarta, Khairul Bayan Press. 
Apriyantono, A. (2009) Potensi Ketidakhalalan Produk Pangan dan Masalah Pangan hasil Rekayasa Genetika. Bandung, PT Kiblat Buku Utama.

[BPS] Badan Pusat Statistika. Berita Resmi Statistik: Pertumbuhan Ekonomi Triwulan II-2017 [internet]. [diunduh 2017 Sept 14]. Tersedia pada: https://www.bps.go.id.

. Buku 1 Pengeluaran Untuk Konsumsi Penduduk Indonesia Berdasarkan Hasil Susenas Maret 2016 [internet]. [diunduh 2017 Mar 6]. Tersedia pada: https://www.bps.go.id.

Susenas, . Konsumsi per Kapita dalam Rumah Tangga Setahun menurut Hasil http://aplikasi2.pertanian.go.id.

. Penduduk Menurut Wilayah dan Agama yang Dianut (Indonesia) [internet]. [diunduh 2017 Jan 25]. Tersedia pada: http://sp2010.bps.go.id.

- Rata-Rata Pengeluaran per Kapita Sebulan di Daerah Perkotaan Menurut Kelompok Barang (rupiah), 2013-2015 [internet]. [diunduh 2017 Apr 13]. Tersedia pada: https://www.bps.go.id.

Burhanuddin. (2011) Pemikiran Hukum Perlindungan Konsumen dan Sertifikasi Halal. Malang, UINMaliki Press.

Diana, I.N. (2012) Hadis-Hadis Ekonomi Cetakan ke-3. Malang, UIN-Maliki Press.

Hidayat, A. (2015) Interpretasi Regresi Logistik dengan SPSS [internet]. [diunduh pada 2017 Agust 13]. Tersedia pada: http://www.statistikian.com.

Idrus, M. (2009) Metode Penelitian Ilmu Sosial: Pendekatan Kualitatif dan Kuantitatif Edisi ke-2. Jakarta, Erlangga.

[KEMENDAG] Kementerian Perdagangan Republik Indonesia, Pusat Kebijakan Perdagangan Dalam Negeri. (2013) Laporan Akhir Analisis Dinamika Konsumsi Pangan Masyarakat Indonesia [internet]. [diunduh 2017 Feb 10]. Tersedia pada: http://www.kemendag.go.id.

[LPPOM MUI] Lembaga Pengkajian Pangan Obat obatan dan Kosmetika Majelis Ulama Indonesia. Jumlah Sertifikasi Halal MUI tahun 2010-2015 [internet]. [diunduh 2017 Jan 30]. Tersedia pada: http://www.halalmui.org.

Tersedia pada: http://www.halalmui.org.

[P3EI UII] Pusat Pengkajian dan Pengembangan Ekonomi Islam Universitas Islam Indonesia. (2013) Ekonomi Islam Cetakan ke-5. Jakarta, PT Raja Grafindo Persada.

Puspitawati, H. (2013) Pengantar Studi Keluarga. Bogor, IPB Press.

Sawit, H.M. (2003) Kebijakan gandum/terigu: Harus mampu menumbuhkembangkan industri pangan dalam negeri. Analisis Kebijakan Pertanian, 1(2), 100-109.

Sukesti, F. \& Mahdukh, B. (2014) The influence halal label and personal religiousity on purchase decision on food products in Indonesia. International Journal of Business, Economics and Law, 4(1), 150-153.

Suliyanto. (2009) Metode Riset Bisnis Edisi ke-2. Yogyakarta, ANDI.

Syarbini, M.H. (2016) A-Z Bakery: Referensi Komplet Fungsi Bahan, Proses Pembuatan Roti, panduan Menjadi Bakepreneur Cetakan ke-2. Solo, Tiga Serangkai.

Reuters, T. \& Standard, D. (2015) State Of The Global Islamic Economy 2014 - 2015 Report [internet]. [diunduh 2017 Apr 6]. Tersedia pada: http://www.flandersinvestmentandtrade.com.

Widianis, D. (2014) Pola Konsumsi Pangan Rumah Tangga Miskin di Provinsi Nusa Tenggara Timur [tesis]. Bogor, Institut Pertanian Bogor. 